IJLR: International Journal of Law Recontruction

Volume 5, Number 2, September 2021

DOI : http://dx.doi.org/10.26532/ij|r.v5i2.14973

\title{
GOOD CORPORATE GOVERNANCE (GCG) PRINCIPLE IN SHARIA BANKING: AN ISLAMIC LAW PERSPECTIVE
}

\author{
Suryani \\ Universitas Islam Negeri Sultan Maulana Hasanuddin Banten \\ suryani@uinbanten.ac.id \\ Yudi Ahmad Faisal \\ Fakultas Ekonomi dan Bisnis, Universitas Padjadjaran \\ yudi.ahmad@unpad.ac.id \\ Muhammad Anwar Fathoni \\ Universitas Pembangunan Nasional Veteran Jakarta \\ mfathoni@upnvj.ac.id \\ Lukman Santoso \\ Institut Agama Islam Negeri Ponorogo \\ lukmansantoso4@gmail.com
}

\begin{abstract}
The implementation of Islamic economy in Indonesia is due to the fact that Islam has a comprehensive and universal teaching in all human life aspects, including economy. One encouraging sharia banking development in Indonesia is indicated by the operation of banks accommodating the sharia principles. The rapid development of sharia banking requires an immediate implementation of Good Corporate Governance (GCG) system to provide a maximum protection for the stakeholders, especially customers. The implementation of GCG is expected to help sharia banking minimize the poor financing quality, increase the bank assessment accuracy, infrastructure, and business decision making quality as well as become the early detection to high risk business areas, products, and services. The implementation of GCG system is greatly important since sharia banking is the intermediary institution requiring the public or stakeholders' trust.
\end{abstract}

Keywords: Good Corporate Governance (GCG), Sharia Banking, Islamic Law.

\section{A. INTRODUCTION}

Economic activity is one mu'âmalah aspect of Islamic systems due to the utilization of fiqh principles to identify the economic transactions which also use the mu'âmalah fiqh principles. One mu'âmalah fiqh principle is "alashlu fî al-mu'âmalati al-ibâhah hattâ yadullu ad-dalîilu 'ala tahrîmiha" (law provenience in mu'âmalah affairs is allowed, except there is a forbidding proposition). This means that anything related to mu'âmalah which has no provisions in the forms of prohibitions or recommendations stated in the Islamic propositions (al-Qur'an and al- Hadîst) is allowed in Islam. 
A quite fundamental Islamic economic development in banking sector is the operation of sharia banking in Indonesia initially referring to the application of banking Act No. 7 of 1992 which provided opportunities for a bank operating based on sharia systems. In addition, the issuance of Act No. 10 of 1998 further allowed banks to change their operation systems to sharia bank either simultaneously or partially by setting up their sharia bank branches.

The implication of provisions contained in Act No. 21 of 2008 on Islamic banking which obliged the Conventional Commercial Banks (CCBs) to spin-off their Sharia Business Units (SBUs) into Sharia Commercial Banks (SCBs) if the value of their Sharia Commercial Banks' (SCBs') assets has reached at least $50 \%$ from that of the holding bank or no later than 15 years since the application of this law that the number of Sharia Commercial Banks (SCBs) will increase in the future.

The growth of sharia banks is relatively high indicated by their volumes of 14 Sharia Commercial Banks (SCBs), 20 Sharia Business Units (SBUs), and 164 Sharia Public Financing Banks (SPFBs). When generally compared to the conventional commercial banking or globally to sharia financial banking in the middle of these recovering economic conditions, the national sharia banks have been able to maintain their existence and development in facing the economy situations even with some arising challenges, such as human resources, products, networks and capitals when compared to the conventional banks and global sharia banking.

The shift of sharia banking supervisory and regulatory institution from Bank Indonesia (known as BI) to Financial Services Authority (known as OJK/Otoritas Jasa Keuangan) is expected to continuously maintain the sharia banks sustainable development in the future. Strong cooperation between BI (macro-prudential authority) and OJK (micro-prudential authority) may become one important pillar of sharia banking policy directions in the future.

Islamic Economic Movement Implementation (GRES) is the running Islamic education program recently improved to strengthen the sharia financial development as one priority to strengthen the sharia financial system stability and improve the economic contribution based on sharia principles within the national economic growth through the infrastructure development of laws, institutions, and markets.

The recent rapid development of sharia banking requires the immediate implementation of Good Corporate Governance (GCG) practices in banking management to provide maximum protection to all parties interested in the stakeholders, especially the customers and depositors. Besides, the implementation of Good Corporate Governance (GCG) helps sharia banks minimize their poor financing quality, improve their bank assessment accuracy, infrastructure, business decision-making quality, and early detection system to high-risk business areas, products, and services. Therefore, good corporate governance may be realized if the Indonesian Muslim citizens and government make the Islamic laws as guidelines for each life conduct and behavior, because the basic principles to establish the Islamic laws are general benefits through the reinforcement of five basic 
principles (al-ushul al-khamsah); maintaining religion (hifz al-din), maintaining soul (hifz al-nafs), maintaining mind (hifz al-'aql), maintaining descendant (hifz al-nasl), and maintaining wealth (hifz al-mal).

Research on Good Corporate Governance (GCG) is mostly carried out using a comparative approach, and research on it that using an Islamic law approach is still rare. Most of the previous studies only compared the practice of good governance in Islamic financial institutions and conventional financial institutions. Alnasser and Muhammed $(2012)^{1}$ compare the difference between normal corporate governance in conventional banking and compare it with Islamic banking. They conclude that it is very important to take into consideration the corporate governance in Islamic banks because it might help to draw the right image about the organization. In particular, how the sharia supervisory board functions and how it could be linked to the Islamic banking process.

Bukhari, Awam and Ahmed (2013)2 also evaluate corporate governance practices of Islamic banks versus Islamic bank windows of conventional banks in Pakistan. The study found that the most significant dimensions which affect the corporate governance in Islamic banks are Board of Directors (BOD) and Sharia Supervisory Board (SSB), while the significant factors for Islamic banking windows are almost all dimensions of corporate governance. These indicate that there is a significant difference between Islamic banks and Islamic banking windows regarding the BOD and SSB. On the other hand, no significant difference is seen for the rest of the factors.

Choudhury and Alam (2013) also researched this topic with an epistemological approach. ${ }^{3}$ They conclude that the heterodox theory of Islamic finance in regards to the theme of corporate governance is shown to be a viable alternative way of understanding this topic in the light of the particular Islamic epistemological premise. Thus, Islamic financial perspective, exemplified here in terms of corporate governance, is expounded.

Based on the explanation above, it is still rare for research to focus on the study of developing corporate governance based on Islamic law. The novelty of this research is the analysis of corporate governance using the perspective of Islamic law. Through this point of view, it is hoped that this article can contribute to the renewal of literature related to good governance.

1 Sulaiman Abdullah Saif Alnasser, Joriah Muhammed, Introduction to Corporate Governance from Islamic Perspective, Humanomics, Vol. 28, No. 3, 2012, page. 220-231.

2 Khuram Shahzad Bukhari, Hayat M. Awan, Faareha Ahmed, An Evaluation of Corporate Governance Practices of Islamic Banks Versus Islamic Bank Windows of Conventional Banks: A Case of Pakistan, Management Research Review, Vol. 36, No. 4, 2013, page. 400-416.

3 Masudul Alam Choudhury, Mohammad Nurul Alam, Corporate Governance in Islamic Perspective, International Journal of Islamic and Middle Eastern Finance and Management, Vol. 6, No. 3, 2012, page. 180-199. 


\section{B. RESEARCH METHODS}

This study uses a qualitative method with a library research approach. Library research is a method that looks for references that are relevant to the problems found. Literature studies describe theoretical analysis, scientific studies, references and literature related to the habits, norms and values of the local community which are built on the observed field conditions. ${ }^{4}$

The data used is secondary data, namely data sourced from existing literature or references, such as those found in scientific journals and papers, encyclopedias, literature, and other data sources related to the research topic. The analysis technique in this study uses a technique where studies of data sources are studied so as to produce conclusions that are actually in accordance with the research topic.

\section{RESULT AND DISCUSSION}

\section{Islamic Law Conception}

Islamic law is defined by some Islamic figures (ulama) different from sharia and figh. Those two latest terms are frequently used in Arabic literatures and also frequently different when translated to other languages. According to Syekh Mahmud Syaltut, sharia terminologically means laws and regulations from Allah to His servants. Manna' al-Qathan was added with aspects related to faith, worship, moral and mu'âmalah.

According to Abu Zahrah, Fiqh is terminologically defined as knowing the syara' laws within the 'amaliyah manners studied from its proposition in details. Meanwhile, Hukum Islam is a typical Indonesian term literally translated from the Western literature of Islamic Law. Haby Ash-Shieddiegy, in his book defined Islamic law as "the collection of fuqaha efforts in applying the Islamic sharia based on people's needs".

Meanwhile, law in Islamic perspective is frequently defined as a set of rule systems established by Allah as the guidelines for humans, either in their relationship with Allah (habl min Allah) or their relationship with the other humans (habl min al-nas). In different language, Abu Zahra argued that law refers to syar'i commands (khitab) closely related to the mukallaf conducts, either in the form of guidance, choice, or establishment.

Abdurrahmad Wahid argued that Islamic law is commonly known as fiqh and frequently called sharia. It is named fiqh since showing its scope totality in life that its implementation in all life aspects should be assumed as one religious understanding effort itself. ${ }^{5}$ Meanwhile, Ibrahim Husen argued that figh and sharia should be differently defined. Figh is a product of human thoughts which is relative to the sharia established by Allah SWT, while sharia refers to the absolute, universal, and eternal Islamic values. The argument is more or less in line with the definitions proposed by Rifyal Ka'bah arguing that Islamic sharia has three definitions: first, as the whole religion brought by The Prophet

4 Sugiyono, Metode Penelitian Kualitatif, Kuantitatif dan R\&D, Alfabeta, Bandung, 2017, page. 224.

5 Abdurrahman Wahid, Tuhan Tidak Perlu Dibela, LkiS, Yogyakarta, 1999, page. 89. 
Muhammad SAW; second, the whole nash (al-Qur'an and al- Hadîst) as the law values originated from the revelation conveyed by Allah; third, the understanding derived from experts to law and ijtihad result based on the revelation conveyed by Allah, which frequently named as fiqh or Islamic law. ${ }^{6}$

Islamic law which is based on nususshar'iyyah is not automatically limited only to its views on the worldly consequences, but also considering the ukhrawi consequences, that is, life consequences after the world has ended.

In a nation which is based on five basic principles (known as Pancasila) and its majority Muslim population, the consequence is that the laws applicable in Indonesia should be consistent and based on the values of belief in the one and only God (known as Ketuhanan Yang Maha Esa as the first basic principle of Pancasila which inspires the other principles) and still beatifies the values of Islamic law.

Indonesian Muslim communities have accepted Pancasila as the national basic principle since the basic principles of Pancasila are not in contradiction with the Islamic Law and in line with the Islamic teachings, as proven that Pancasila was written in the Jakarta Charter (known as Piagam Jakarta). Thus, Islamic law has become one positive legal source in legislative processes based on Pancasila.

The regulations of law sourced from and containing the established Islamic law in the form of applicable laws include: Zakat Management, Act No. 17 of 1999 on Pilgrimage Organization, Act No. 10 of 1998 on Banking, Act No. 41 of 2004 on Waqf, Act No. 3 of 2006 on the amendment of Act No. 7 of 1989 on Religious Court, Act No. 18 of 2001 on Special Autonomy for Aceh Province special region in which the government gives wider authorities for government administration as well as human and natural resource management, including the enforcement of Islamic sharia, Act No. 13 of 2008 on Pilgrimage Organization as the substitution for Act No. 17 of 1999, Act No. 21 of 2008 on Sharia Banking and Act No. 19 of 2008 on State Sharia Securities.

\section{Good Corporate Governance (GCG) in Sharia Banking}

Good Corporate Governance (GCG) may be approached with various disciplines such as macroeconomics, theory of organization, information, accounting, finance, management, psychology, sociology, and politics.

The term "government" and "governance" in dictionary are frequently considered having the same meaning, that is, the way to implement authorities in an organization, institution, or country. Government is a name given to an entity implementing the government's power in a country. ${ }^{7}$

World Bank defines good governance as solid and responsible

6 Rifyal Ka'bah, Penegakan Syariat Islam di Indonesia, Khairul Bayan, Jakarta, 2004, page. 42.

7 Joko Widodo, Good Governance, Insan Cendikia, Surabaya, 2002, page. 19. 
implementation of state development management efforts in line with the democracy principles and efficient markets, investment fund misallocation avoidance and corruption prevention both politically and administratively, performing budget disciplines as well as the legal and political framework creation for business activity growth. ${ }^{8}$

Corporate governance is the relationship between shareholders in deciding the policy directions and company's performance. The main purpose of Good Corporate Governance (GCG) is to create check and balance system to avoid the company resource misappropriation and to continuously encourage the company's growth. ${ }^{9}$

Based on the juridical principles of Good Corporate Governance (GCG) established by BI in Bank Indonesia's Regulation No. 8/4/PBI/2006 and amended to Bank Indonesia Regulation No. 8/14/PBI/2006 on Good Corporate Governance (GCG) implementation for Commercial Banks. Act No. 21 of 2008 on Sharia Banking decided that in implementing its businesses, sharia banks and sharia business units should well fulfill the good corporate governance, precautionary principle and risk management. Besides, sharia banks and sharia business units should implement the principle of acknowledging and protecting the customers including the obligation to explain the possible losing risks related to the customers' transactions made through sharia banks. ${ }^{10}$

Bank Indonesia circular letter No. 12/12/DPbS on 30 April 2010 on Good Corporate Governance (GCG) implementation for sharia commercial banks and Sharia business units is in conjunction with the technical rule implementation of Bank Indonesia's Regulation No. 11/3/PBI/2009 on 29 January 2009 on Sharia Commercial Banks, Bank Indonesia's Regulation No. 11/10/PBI/2009 on 18 March 2009 on Sharia Business Units, and Bank Indonesia's Regulation No. 11/33/PBI/2009 on 7 December 2009 on Good Corporate Governance (GCG) implementation for Sharia Commercial Banks (SCBs) and Sharia Business Units (SBUs).

Good Corporate Governance (GCG) implementation in sharia banks is expected to increase their added values for the stakeholders. Effective company management practices may increase the company's accountability. An organization or company which focuses more on its sustainability practices has higher financial performance than that which has no commitment in some activity sectors. ${ }^{11}$

Good Corporate Governance (GCG) implementation in sharia banking industries in Indonesia is based on five basic principles as regulated in Bank Indonesia's Regulation No. 11/33/PBI/2009 on Good Corporate Governance (GCG) implementation for Sharia Commercial Banks (SCBs) and Sharia Business Units (SBUs).

8 Sudarmayanti, Good Governance II, Mandar Maju, Bandung, 2004, page. 4.

9 Masudul Alam Choudhury and Mohammad Nurul Alam, Corporate Governance in Islamic Perspective, International Journal of Islamic and Middle Eastern Finance and Management, Vol. 6, No. 3, August 2013, page. 180-199.

10 Act No. 21 of 2008 on Sharia Banking in Article 34, 35, 38, and 39.

11 Mongi Lassoued, Corporate Governance and Financial Stability in Islamic Banking, Managerial Finance, Vol. 44, No. 5, 2018, page. 524-539. 
First, transparency is the openness in delivering materials and relevant information as well as the openness in the decision-making processes.

Second, accountability is the function clarity and the responsibility implementation of bank's organs that its management may run effectively.

Third, responsibility is the bank management appropriateness with the applicable regulations of law and healthy bank management principles.

Fourth, professional is having competencies, able to act objectively and free from any party's influence or pressure (independent) and having a high commitment to develop sharia banks.

Fifth, fairness is justice and equality in fulfilling the stakeholders' rights based on the applicable agreement and regulations of law. Good Corporate Governance (GCG) implementation in sharia banking is conducted to protect the stakeholders' interests and increase the obedience to the applicable regulations of law and general ethical values in sharia banking industries.

Good Corporate Governance (GCG) principles in sharia banking are basically the main principles and best practices of Good Corporate Governance (GCG) developed in sharia banking similar with those in conventional banks.

Factors to notify in developing the concept of Good Corporate Governance (GCG) are cultural management, accounting, and supervision. Management and accounting based on Islam are greatly important to support the Good Corporate Governance (GCG) implementation practices in Islamic financial institutions, especially in sharia banking, ${ }^{12}$ because those factors will later influence many elements, such as stakeholders' rights protection. The term "stakeholder" in sharia banking includes shareholders, bank management, employee, and Investment Account Holder (IAH). Investment Account Holder (IAH) is customers or depositors in conventional banking. The effective company management implementation in sharia banking requires understanding related to Good Corporate Governance (GCG) principles includes:

a. Accountability means the demands for company management to have the answerability competencies to respond questions from the stakeholders on various corporate actions. 13

b. Transparency means the availability of accurate, relevant, and understandable information possibly obtained in low-cost so that the stakeholders possibly make the right decision. Thus, the company

12 Murniati Mukhlisin and Leny Nofianti, The Role of Good Corporate Governance and Accounting in Islamic Financial Institutions, in Research in Corporate and Shari'ah Governance in the Muslim World: Theory and Practice, Emerald Publishing Limited, 2019, page. 115-126.

13 Ibrahim Abiodun Oladapo et al., Perception of Stakeholders on Governance Dimensions of the Islamic Banking Sector, International Journal of Emerging Markets, Vol. 14, No. 4, October 2019, page. 601-619. 
needs to improve its quality, quantity, and frequency related to the company's activity report.14

c. Responsibility makes sure that the bank is managed carefully in accordance with the applicable regulations of law, including establishing the appropriate risk management and control.

d. Independency is conducted based on the bank's interest and not influenced by the activities leading to the conflict of interests.

e. Fairness guarantees the protection of rights belonging to the shareholders, management, and bank employees, customers, and other stakeholders.

In Islamic teachings, those five GCG basic principles are in accordance with the Islamic norms and values in a Muslim's activities. Islam intensively teaches the implementation of principles justice ( adalah), balance (tawazun), accountability (mas'uliyah), morality (akhlaq), honesty (shiddiq), trust (amanah), intelligence (fathanah), transparency, openness (tabligh), independency and responsible freedom (hurriyah), professional (ihsan), fairness (wasathan), sharia militancy (ghirah), management (idarah), leadership (khilafah), faith (aqidah), positive thinking (ijabiyah), supervision (raqabah), the continuously learning and making improvement organization (qira'ah and ishlah).

Based on the explanations above, it is proven that Islam has existed long before the birth of Good Corporate Governance (GCG) which becomes the reference for good company management in the world. Those principles are expected to professionally maintain the sharia economic institutional and financial management and maintain the economic, business, and social interactions in accordance with the applicable rules and best practices.

The purpose of Good Corporate Governance (GCG) implementation in sharia banking is to increase the added values for the stakeholders as follows:

a. Increasing efficiency, effectiveness, and sustainability of an organization contributing to the creation of welfare for the shareholders, employees, and other stakeholders as well as becoming an elegant solution to face the future challenges.

b. Increasing the organization legitimation which is openly, fairly, and accountably managed.

c. Acknowledging and protecting the stakeholders' rights and obligations.

d. An integrated approach based on the democratic principles, organization's legitimate management and participation.

e. Minimizing the agency cost by controlling the possibly arising conflict of interests between principal parties and agents.

f. Minimizing the capital cost by giving a positive signal to the capital

14 Yaser Ahmed Fallatah, Abul Hassan Farooqi, and Salah al Shalhoob, A Perspective of the Shari'ah Compliant Corporate Governance of Financial Institutions in Saudi Arabia and Agency Structures, in Research in Corporate and Shari'ah Governance in the Muslim World: Theory and Practice (Emerald Publishing Limited), 2019, page. 287-303. 
providers and increasing the company's values resulted from the lower capital costs, improving financial performance and better perception from the stakeholders related to the company's performance in the future.

Thus, through some purposes above, the Good Corporate Governance (GCG) implementation in sharia banking is expected to:

a. Increase the public trust on sharia banks;

b. Grow the sharia financial service industries and continuously stabilize the simultaneous financial system; and

c. Succeed the sharia financial services in implementing the GCG to locate the sharia financial institutions to have the level of playing field equally with other international financial institutions.

Besides, we also need to build an effective Good Corporate Governance (GCG) system for sharia banks by paying more attention to some Good Corporate Governance (GCG) mechanism pillars as follows:

a. Roles and responsibility of Sharia Supervisory Board (SSB) should be optimized to make sure that all transactions made by the company do not violate the sharia principles;

b. Islamic banks should have a strong internal supervision system and risk management. This is important to detect and avoid mismanagement and fraud or system and procedure failure in sharia banks;

c. In sharia context, external auditors do not only have the role to give opinions that the bank's financial reports have been fairly presented in accordance with the applicable accounting standard. External auditors should also work together and correlate their works to the Sharia Supervisory Board (SSB) and make sure that the financial report presentation has an adequate disclosure and transparency level;

d. Islamic corporate culture transformation and human resource quality improvement should become the sharia bank management's commitment;

e. Regulations of laws belonging to Bank Indonesia and capital market in accordance with the sharia bank characteristics have become the requirement to create a healthy GCG and supervision climate for sharia banks in Indonesia.

\section{The Implementation Urgency of Good Corporate Governance (GCG) Principles in Sharia Banking Practices}

The implementation of GCG principles has become inevitability for any institution, including sharia bank institutions due to the public accountability related to the banking operational activity which is greatly expected to obey the provisions written in the positive law, such as Act No. 1 of 1995 on Limited Liability Company and Act No. 20 of 1998 on the amendment of Act No. 7 of 1992 on banking including its implementation rules. Besides, it is also related to the obedience of 
sharia banks to the sharia principles as mentioned in al-Qur'an, alHadîst, and ijma' of ulama.

Regarding to the definition of Good Corporate Governance (GCG) in the banking world, we may read the provisions contained in article 1 Point 6 of Bank Indonesia's Regulation No.8/4/PBI/2006 on Good Corporate Governance for Commercial Banks. Good Corporate Governance (GCG) is the bank management implementing the principles of transparency, accountability, responsibility, independency, and fairness.

The general explanations contained in Bank Indonesia's Regulation No. 8/4/PBI/2006 proposes the meaning from each principle of Good Corporate Governance (GCG) as follows:

First, transparency is defined as the openness in delivering materials and relevant information and in performing the decision-making processes. Second, accountability is the clarity of bank's function and responsibility that the management runs effectively. Third, responsibility is the bank management appropriateness with the applicable regulations of law and healthy bank management principles. Fourth, independency is professional bank management without any party's influence/pressure. Fifth, fairness is justice and equality in fulfilling the stakeholders' arising rights based on the agreement and applicable regulations of law.

The GCG in financial institutions, especially banks, have the uniqueness when compared to the non-bank financial institutions' governance due to the existence of depositors as a group of stakeholders whose interests should be well accommodated and maintained. Meanwhile, in sharia banks, there are sharia principles supporting the implementation of GCG principles that the law subjects including banks are required to implement the principles of honesty (shiddiq), education to the society (tabligh), trust (amanah), and professional management (fathanah).

Corporate Governance is a conception really explained in the form of provisions/rules made by the authority institutions, norms and ethics developed by the industrial association and adopted by industrial actors and institutions related to the obvious tasks and roles to encourage the disciplines, overcome the impacts of moral hazard, and implement check and balance functions. Some basic instruments required to establish the Good Corporate Governance (GCG) in sharia banks include: internal control system, risk management, provisions leading to information openness improvement, accounting system, sharia compliance guarantee mechanism, and external audit.

Sharia banks are juridical responsible to many stakeholders including depositors, shareholders, obligation investors, corresponding banks, regulators, company employees, suppliers as well as public and environment. Thus, the implementation of Good Corporate Governance (GCG) is a necessity for each sharia bank. The implementation of Good Corporate Governance (GCG) is a form of sharia bank's accountability to public that the Islamic bank is professionally, prudently, and well managed by continuously maintaining the shareholder's value 
improvement without ignoring the other stakeholders' interests.

The implementation of Good Corporate Governance (GCG)

principles by a bank, including sharia bank should at least be realized in:

a. Implementation of tasks and responsibilities by the Board of Commissioners, Board of Sharia Supervisors and Board of Directors;

b. Task completeness and implementation by the committees and working units operating the bank's internal control functions;

c. Implementation of compliance function, internal auditor, and external auditor;

d. Implementation of risk management, including internal control system;

e. Provision of funds to the related parties and large provision of funds;

f. Bank's strategic plans;

g. Transparency of bank's financial and non-financial conditions.

Banking authorities are required to anticipate the arising challenges related to the implementation of sharia banks' Good Corporate Governance (GCG) in Indonesia. Some Good Corporate Governance (GCG) principles have been recently well fulfilled by the sharia banks, such as by forming the law rules and special institutions for sharia banks to manage the sharia bank structures and organizations, requirements for owners and managers, fit and proper test mechanisms and rules, bank obligation to form an internal audit working unit, disclosure provision, accounting standard, and implementation of risk management arranged in details within the Indonesia Bank's Regulation No. 8/4/PBI/2006 on the Implementation of Good Corporate Governance for Commercial Banks.

The supporting elements for the sharia banks' Good Corporate Governance (GCG) principles are National Sharia Board (NSB), Sharia Supervisory Board (SSB), Customer Complaint Agency, Banking Mediatory Institution, and National Sharia Arbitration Institution (known as BASYARNAS). The supports for sharia banks' Good Corporate Governance (GCG) are also given by Bank Indonesia (BI) as the national banking authority by setting the special code of ethics for sharia banks' Good Corporate Governance, while the international sharia institutions, such as Islamic Financial Services Board (IFSB) in 2005 has completed the standard guidelines of Good Corporate Governance for International Islamic financial institutions. ${ }^{15}$

\section{CONCLUSION}

Sharia principles are part of Islamic system. Good Corporate Governance (GCG) principles strongly support the sharia institutions since in line with the syar'i principles such as: equality, transparency, accountability, responsibility, morality, commitment, and independency. Meanwhile, there

15 Muhammad Iman Sastra Mihajat, Shari'ah Governance Framework in Islamic Banking and Financial Institutions in Indonesia: A Proposed Structure, in Research in Corporate and Shariah Governance in the Muslim World: Theory and Practice, Emerald Publishing Limited, 2019, page. 239-248. 
are mu'âmalah principles in Islam such as: balance (tawazun), accountability (mas'uliyah), morality (akhlaq), honesty (shiddiq), trust (amanah), intelligence (fathanah), transparency/openness (tabligh), independency and responsible freedom (hurriyah), professional (ihsan), airness (wasathan), Islamic militancy (ghirah), management (idarah), leadership (khilafah), faith (aqidah), positive thinking (ijabiyah), supervision (raqabah), the continuously learning and making improvement organization (qira'ah and ishlah).

The implementation of GCG is greatly important since sharia banking is the intermediary institutions requiring the public trust that they are trusted by all stakeholders. To create a healthy climate for the implementation of GCG in sharia banks, all stakeholders should be simultaneously involved in sharia banks. However, it should be noted that the most determining actor is the sharia bankers themselves. They must have a strong determination and commitment to implement the GCG in their institutions. Besides, the involvement of all parties is greatly required through a harmonious cooperation between ulama, bank customers, academicians, and governments to encourage the sharia banking performance in obeying the Good Corporate Governance (GCG) principles.

\section{BIBLIOGRAPHY}

\section{Books:}

Abdurrahman Wahid, 1999, Tuhan Tidak Perlu Dibela, LkiS, Yogyakarta;

Joko Widodo, 2002, Good Governance, Insan Cendikia, Surabaya;

Muhammad Abu Zahrah, 1958, Ushul al-Fiqh, Dar al-Fikr al-'Arabi, Beirut;

Rifyal Ka'bah, 2004, Penegakan Syariat Islam di Indonesia, Khairul Bayan, Jakarta;

Sudarmayanti, 2004, Good Governance II, Mandar Maju, Bandung;

Sugiyono, 2017, Metode Penelitian Kualitatif, Kuantitatif dan R\&D, Alfabeta, Bandung;

\section{Journals:}

Ibrahim Abiodun Oladapo et al., Perception of Stakeholders on Governance Dimensions of the Islamic Banking Sector, International Journal of Emerging Markets. Vol. 14, No. 4, October 2019;

Khuram Shahzad Bukhari, Hayat M. Awan, Faareha Ahmed, An Evaluation of Corporate Governance Practices of Islamic Banks versus Islamic Bank Windows of Conventional Banks: A Case of Pakistan, Management Research Review, Vol. 36, No. 4, 2013;

Masudul Alam Choudhury and Mohammad Nurul Alam, Corporate Governance in Islamic Perspective, International Journal of Islamic and Middle Eastern Finance and Management, Vol. 6, No. 3, August 2013; 
Mongi Lassoued, Corporate Governance and Financial Stability in Islamic Banking, Managerial Finance, Vol. 44, No. 5, 2018;

Muhammad Iman Sastra Mihajat, Shari'ah Governance Framework in Islamic Banking and Financial Institutions in Indonesia: A Proposed Structure, in Research in Corporate and Shariah Governance in the Muslim World: Theory and Practice, Emerald Publishing Limited, 2019;

Murniati Mukhlisin and Leny Nofianti, The Role of Good Corporate Governance and Accounting in Islamic Financial Institutions," in Research in Corporate and Shariah Governance in the Muslim World: Theory and Practice, Emerald Publishing Limited, 2019;

Sulaiman Abdullah Saif Alnasser, Joriah Muhammed, Introduction to Corporate Governance from Islamic Perspective, Humanomics, Vol. 28, No. 3, 2012;

Yaser Ahmed Fallatah, Abul Hassan Farooqi, and Salah al Shalhoob, A Perspective of the Shari'ah Compliant Corporate Governance of Financial Institutions in Saudi Arabia and Agency Structures, in Research in Corporate and Shariah Governance in the Muslim World: Theory and Practice, Emerald Publishing Limited, 2019;

\section{Regulation:}

Act No. 21 of 2008 on Sharia Banking in Article 34, 35, 38, and 39. 